\title{
DO HOUSE PRICES REFLECT FUNDAMENTALS? AGGREGATE AND PANEL DATA EVIDENCE
}

\author{
Vyacheslav Mikhed \\ Petr Zemčík
}
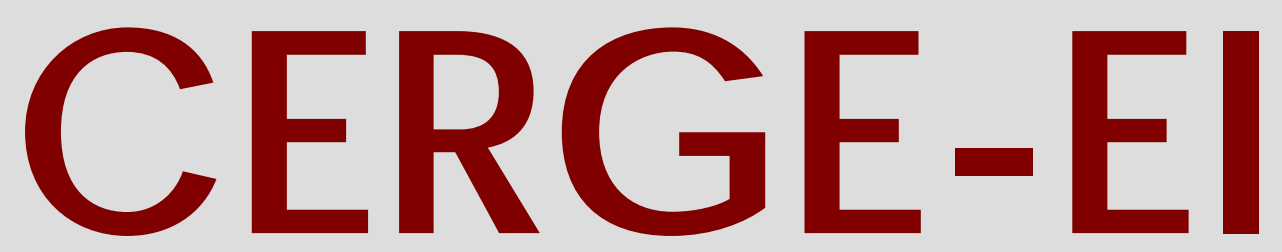

Charles University CenterforEconomic Research and Graduate Education Academy of Sciences of the Czech Republic Ec onomic s Institute 


\title{
Working Paper Series 337 (ISSN 1211-3298)
}

\section{Do House Prices Reflect Fundamentals? Aggregate and Panel Data Evidence}

\author{
Vyacheslav Mikhed \\ Petr Zemčík
}

CERGE-EI

Prague, October 2007 
ISBN 978-80-7343-136-5 (Univerzita Karlova. Centrum pro ekonomický výzkum a doktorské studium)

ISBN 978-80-7344-125-8 (Národohospodářský ústav AV ČR, v.v.i.) 


\title{
Do House Prices Reflect Fundamentals? Aggregate and Panel Data Evidence
}

\author{
Vyacheslav Mikhed and Petr Zemčík*
}

CERGE-EI ${ }^{\dagger}$

October 2007

\begin{abstract}
We investigate whether recently high U.S. house prices are justified by fundamental factors. The standard unit root and cointegration tests with aggregate data indicate that house rent is the only fundamental which has the same order of integration as the price, but these two variables are not cointegrated. Nationwide analysis potentially suffers from problems of the low power of stationarity tests applied to relatively short series and the ignorance of dependence among regional house markets. Therefore, we conduct panel data stationarity tests which are robust to cross-sectional dependence and have greater power than univariate tests. While this time it is inflation and income that have the same order of integration as house price, they are not cointegrated with it, even if combined with the aggregate stock index. It appears that the real estate prices take long swings from their fundamental value and it can take decades before they revert to it.
\end{abstract}

\begin{abstract}
Abstrakt
Zkoumáme, zda fundamentální faktory dostatečně vysvětlují nedávno zvýšené ceny domů v USA. Výsledky standardních testů pro jednotkové kořeny a kointegraci $\mathrm{v}$ agregovaných datech ukazují, že jedině nájem je proměnná se stejnou úrovní integrace, jako cena domů. Mezi těmito proměnnými ale není kointegrace. Síla testu stacionarity je $\mathrm{v}$ tomto př́padě potenciálně nízká kvůli malému počtu pozorování $\mathrm{v}$ časových řadách a kvưli tomu, že tyto testy nepočítají se závislostí proměnných mezi regiony. Pro zvýšení síly testu používáme testy stacionarity v panelových datech, jež jsou robustní vzhledem ke zmíněné heteroskedasticitě. I když v tomto př́padě mají stejnou úroveň integrace s cenou domů inflace a př́ijem, ani jedna z těchto proměnných není s cenou zkointegrována. Výsledky naznačují, že ceny domů se na dlouhá období odchylují od rovnovážné ceny a může trvat i několik desetiletí než se k ní vrátí.
\end{abstract}

Keywords: cointegration, panel data, unit root, bubble, house prices, rents JEL classification: G12 - Asset Pricing; R21 - Housing Demand; R31 - Housing Supply and Markets; C33 - Models with Panel Data.

\footnotetext{
*Email: petr.zemcik@cerge-ei.cz

${ }^{\dagger}$ A joint workplace of the Center for Economic Research and Graduate Education, Charles University, Prague, and the Economics Institute of the Academy of Sciences of the Czech Republic.

Address: CERGE-EI, P.O. Box 882, Politických vezňů 7, Prague 1, 111 21, Czech Republic
} 


\section{IS THERE A HOUSE MARKET BUBBLE?}

Recently, the possibility of a house price bubble in the U.S. housing market became an active topic of discussion in both the popular press and academic journals. This issue is of interest because a bursting bubble in a housing market can lead to a decrease in the value of household wealth. According to the 2004 Survey of Consumer Finances, primary and other residential property constituted almost $39 \%$ of the total assets in the portfolios of U.S. families (see Bucks, Kennickell, and Moore [2006]). Therefore, a drop in house prices could result in a severe negative impact on consumption and GDP.

A house price bubble is defined as a situation when a growth of the price is not supported by changes in its fundamentals (Stiglitz [1990]). There are two categories of papers which consider breaks in the relationship between house price and fundamentals. Papers in the first category argue about this issue using aggregate data. For example, McCarthy and Peach [2004] suggest that there is no bubble in the U.S. housing market and that changes in house prices reflect movements in personal income and nominal mortgage rates. Another example of this approach is Shiller [2005] or Gallin [2006] who use aggregate data on home prices, personal income, building costs, population, user costs of housing and interest rates. They show that changes in fundamentals do not explain the rapid growth of U.S. house prices after 2000. The present paper confirms this result using similar data and standard univariate unit root and cointegration tests.

The second stream of this literature relies on regional or micro data in order to get more insights into the behavior of the housing market. For example, Himmelberg, Mayer, and Sinai [2005] use their own calculations of owning costs of housing for 46 Metropolitan Statistical Areas (MSA) to argue that the high price-to-income and price-to-rent ratios observed in recent years are explained by shifts in real long-term interest rates and therefore there is no bubble in the U.S. housing market. Smith and Smith [2006] suggest that house prices are below their fundamental value derived from house rents where prices and rents are taken from a sample of matched single-family homes. Case and Shiller [2003] are more in favor of the existence of a speculative bubble in some regional U.S. housing markets

University, Prague, and the Economics Institute of the Academy of Sciences of the Czech Republic. Address: CERGE-EI, P.O. Box 882, Politických vězňů 7, Prague 1, 111 21, Czech Republic 
based on the results of a survey of consumers' attitudes toward housing.

Finally, Gallin [2006] and Mikhed and Zemčík [2007] both use panel data for the U.S. MSA to analyze house prices. The former study uses income and the latter rent as the only fundamental factor. Both studies employ panel data stationarity tests to find that house price dynamics cannot be explained by either of the two variables. The omission of other potential demand and supply shifters on the housing market could be a reason for the lack of the relationship between the price and fundamentals at the regional level. We construct a panel with other fundamental variables to investigate this possibility. Our regional dataset contains series for regional house prices, rents, Consumer Price Index (CPI), construction costs, income, population and mortgage rates.

Individual time series in our panel are likely to be mutually correlated because close regional house markets tend to be synchronized to some extent. We confirm that cross-sectional dependence is present in our data using a test from Pesaran [2004]. Then we test for unit roots in all of the involved series. Im, Pesaran, and Shin [2003] develop a panel unit root test based on an average of t-statistics for autoregressive coeficients in individual Dickey Fuller regressions. We use an updated version of this test constructed in Pesaran [2007], which is robust to crosssectional dependence. We cannot reject the null hypothesis of a unit root for house prices, regional CPI, and income. If house price dynamics reflects fundamentals the three variables should be cointegrated.

We implement the Pedroni [1999, 2004] statistic to test for panel data cointegration. We account for regional interdependence by bootstrapping critical values using our sample. The house price is not cointegrated with CPI and income even after we account for the aggregate stock market index. The natural conclusion of our paper is that house prices do not reflect fundamentals and this conclusion holds for both aggregate and regional data.

\section{STRUCTURAL MODEL OF THE HOUSING MARKET}

A possible model that explains how house price is related to fundamentals is a structural model of housing supply and demand. According to this model, demand shifters could be personal income, mortgage rate, inflation, house rent, and 
population; supply shifters are building costs, stock market wealth, etc. Two papers which employ structural models to investigate the relationship between house prices and some of the fundamentals are Gallin [2006] and McCarthy and Peach [2004]. For example, a housing demand equation may be as follows:

$$
H_{t}^{d}=\pi_{0}+\pi_{1} P_{t}^{d}+D_{t}
$$

where variables are in logarithms, $H_{t}^{d}$ is quantity of non-rental housing demanded, $P_{t}^{d}$ is the house price consumers are willing to pay, and $D_{t}$ are demand shifters. An equation for housing supply (all variables are in logarithms) is

$$
H_{t}^{s}=\beta_{0}+\beta_{1} P_{t}^{s}+S_{t},
$$

where $H_{t}^{s}$ is the supply of housing, $P_{t}^{s}$ is the price for which suppliers are willing to trade, and $S_{t}$ are supply shifters.

In the long run, a housing market should be in an equilibrium and

$$
H_{t}^{d}=H_{t}^{s}
$$

This condition implies that the equilibrium house price is a function of demand shifters and supply shifters:

$$
P_{t}=\delta_{0}+\delta_{1} D_{t}+\delta_{2} S_{t},
$$

where $P_{t}$ is the equilibrium house price. Of course, this relationship need not be satisfied each time period and it can be rewritten as follows:

$$
P_{t}=\delta_{0}+\delta_{1} D_{t}+\delta_{2} S_{t}+e_{t},
$$

where $e_{t}$ is an error term. This equation tells us that house price can deviate from its fundamentals (demand and supply shifters); however, these deviations should not be persistent. In terms of econometrics, this implication means that house price and fundamentals should be cointegrated or that the error term $e_{t}$ should be 
stationary.

An important point of this model is the choice of supply and demand shifters. Most panel data studies of housing market bubbles concentrate on one fundamental only. This poses a problem because the no cointegration found in those studies may occur due to the ignorance of some fundamentals. In this study we are attempting to consider all the fundamentals regarded as important for a housing market and for which we could find panel data with reasonable cross-section and panel data dimensions. Our variables include house rent, CPI, construction costs, personal income, population, mortgage rates, and stock market wealth.

\section{DATA}

There are two datasets used in this study. The first is the aggregate quarterly U.S. data for 1980:q2-2006:q4 and the second is annual data on 22 U.S. Metropolitan Statistical Areas for 1978-2006. The aggregate data on house prices comes from the quarterly repeat-sales price index of the Office of Federal Housing Enterprise Oversight (OFHEO). ${ }^{1}$ The source of personal income is the Bureau of Economic Analysis. The U.S. Census Bureau provides a measure of population. The average hourly construction wage, ${ }^{2}$ rent of primary residence, and Consumer Price Index (all urban consumers, all items) come from the Bureau of Labor Statistics. A proxy for stock market wealth is Standard and Poor's 500 stock market index. The source of an effective mortgage interest rate is the Federal Housing Finance Board. Since construction wage, rent of primary residence, CPI, mortgage rate, and the S\&P 500 index are in monthly frequency, they are recalculated to the quarterly frequency by taking an arithmetic average of monthly values for a particular quarter. The measure of population is in quarterly frequency for 1980:q2-1990:q4, since the last date quarterly values for population are taken from the monthly estimates.

Panel data on 22 Metropolitan Statistical Areas is annual. All the variables in this dataset and their sources are the same as in the aggregate data except for the construction wage which is substituted by a building cost index. The source of this index is the Engineering News-Record (ENR) cost indexes for 20 U.S. cities. ${ }^{3}$ The two cost indexes published by ENR are the building cost and construction cost indexes. This study uses the building cost index because it better represents build- 
ing works related to residential property, while the construction cost index is more representative for the costs of non-residential property construction. Unfortunately, this index is available for only $16 \mathrm{MSA}$ in the sample.

House rent, CPI, population, building cost index, and per capita income are in annual frequency, so they are not recalculated. The stock market index is available monthly, so annual values are obtained by taking arithmetic averages of monthly values. The house price index is in quarterly frequency, so arithmetic averages of quarterly values are used to get annual estimates. Mortgage rate is annual for 19782004. For 2005-2006 only quarterly values of this rate are available, and therefore averages of quarterly rates are used to obtain annual values. ${ }^{4}$

\section{AGGREGATE DATA EVIDENCE}

This section discusses the behavior of house price and uses logarithms of this price and different fundamentals in order to assess whether the recent U.S. housing market boom can be viewed as a bubble. Also, this section presents unit root and cointegration tests of house prices with the set of fundamentals using aggregate national-level data in order to assess the possibility of a house price bubble.

Exhibits 1 and 2 depict the logarithms of house prices and various fundamentals. The first graph shows a high growth in house prices after 2000 which is not reflected in the time series patterns of rent, income, and CPI. Actually, the growth rate of rent declined in 2000. According to Exhibit 2, population and construction wage are also growing slower than house price in the 2000s. A possible explanation for a faster expansion of the house price is the behavior of the mortgage rate which is declining all over the sample, and it is especially low at the end of the period under study. The low mortgage rate should encourage people to buy houses, increase demand, and possibly cause house prices to rise. Another possible explanation of the high increase of house prices is a crash of the stock market in 2000 and the switching of many stock market investors to the housing market. ${ }^{5}$ An increase in demand for housing generated by these investors could push house prices up. Finally, an important feature of the observed pattern of house prices is a slow-down in the growth of house prices since 2005.

While the graphs provide some intuition about the possible reasons for the 
behavior of house prices in the 2000s, they are not very useful in determining formally whether changes in fundamentals explain changes in house price. In order to test if house prices reflect fundamentals, we use the cointegration procedure developed by Engle and Granger [1987]. Among the fundamentals which will be utilized for cointegration testing are per capita personal income, housing rent, population, Consumer Price Index (CPI), construction wage, mortgage rate, and the stock market index.

Assume that the cointegration regression is as follows:

$$
y_{t}=\mu+\omega t+\sum_{k=1}^{K} \psi_{k} x_{k, t}+\theta_{t}
$$

where $y_{t}$ and $x_{i}(\mathrm{i}=1, \ldots, \mathrm{K})$ are $\mathrm{I}(1)$ variables which are hypothesized to be cointegrated, and $t=1, \ldots, T$ is a time index. According to the Engel and Granger two-stage procedure, in the first stage, it is necessary to test if all variables in the hypothesized cointegration relation are of the same order of integration. After that equation (6) is estimated using OLS and the estimated error term $\hat{\theta}_{t}$ is obtained. At the second stage, testing for the stationarity of $\hat{\theta}_{t}$ is performed using the augmented Dickey-Fuller (ADF) test. If residuals are found to be stationary then the null hypothesis of no cointegration of $y$ and $x_{i}^{\prime} s(\mathrm{i}=1, \ldots, \mathrm{K})$ is rejected. Since a vector of cointegrating parameters $\left(\psi^{\prime} s\right)$ is estimated, the usual critical values for ADF tests cannot be used in this testing, and instead critical values for cointegration tests documented by Davidson and MacKinnon [1993] should be utilized.

According to ADF $\tau$-tests presented in Exhibit 3, the logarithms of per capita personal income, CPI, population, the mortgage rate, and the stock market index have a unit root in levels, but they are stationary in first differences. The logarithm of construction wage is already stationary in levels. Logarithms of house price and rent are not stationary in levels and first differences, but they become stationary in second differences only. According to the Engle and Granger methodology, in order to be cointegrated series must have the same order of integration. Hence, only rent could be potentially cointegrated with house price. However, neither the levels nor first differences of house price and rent are cointegrated. The test statistics are -1.60 and -2.62 . Since the $10 \%$ critical value for these tests is -3.04 
(Davidson and MacKinnon [1993]), the null hypothesis of no cointegration is not rejected. Therefore, the aggregate data on house price and fundamentals suggests that prices do not align with fundamentals and a house price bubble is possible. However, another reason for no cointegration between house price and fundamentals could be the low power of unit root tests in small samples. In order to increase the power of these tests we switch to the panel data analysis.

\section{PANEL DATA EVIDENCE}

Testing for unit roots and cointegration in panel data has made rapid progress in the last fifteen years. Current tests are now robust to cross-sectional dependence and autocorrelation, allow for different autoregressive coefficient across individual units, and have favorable finite sample properties. We perform these tests using panel data on house prices and corresponding fundamental variables.

House prices tend to move together in geographically close areas, which complicates statistical testing for unit roots and cointegration in panel data. Hence, we first test how severe this problem is in our data using a general diagnostic test for cross section dependence in panels from Pesaran [2004]. The test statistic is defined as

$$
C D=\sqrt{\frac{2 T}{N(N-1)}}\left(\sum_{i=1}^{N-1} \sum_{j=i+1}^{N} \operatorname{Corr}\left(\hat{\varepsilon}_{i}, \hat{\varepsilon_{j}}\right)\right)
$$

where $i=1, \ldots, N$ is the the number of individual units and $t=1, \ldots, T$ is the time dimension of the data. $\hat{\varepsilon}_{i}, i=1, \ldots, N$, are $(T \times 1)$ vectors of estimated residuals from the augmented Dickey Fuller (ADF) regression equation:

$$
\Delta y_{i t}=\mu_{i}+\omega_{i} t+\alpha_{i} y_{i, t-1}+\sum_{j=1}^{p_{i}} \lambda_{i j} \Delta y_{i, t-j}+\varepsilon_{i t}
$$

where $\mu_{i}$ is an individual fixed effect, $\omega_{i}$ is an individual trend coefficient and $\alpha_{i}-1$ is an autoregressive coefficient of a given series. Both $\alpha_{i}$ and the lag order $p_{i}$ may vary across cross-sections. The summation term involving lagged $\Delta y$ 's filters out autocorrelation. $C D$ asymptotically converges to the standardized normal distribution. We report the calculated $C D$ statistics for all series in our sample in Exhibit 4 
$\left(p_{i}=1\right)$. There is a strong cross sectional dependence for both the logs and growth rates in all the cases except for the growth rate of the population. Therefore, we will take cross-sectional dependence into account in our testing for unit roots and cointegration.

The standard ADF regression for individual series (such as equation (8)) assumes no cross-sectional dependence. Since this assumption is clearly violated in our data, we conduct an updated version of this test proposed in Pesaran [2007]. Robustness to the cross-sectional dependence in the Pesaran version of the test is achieved by adding the lagged cross-section mean and its differences to the ADF regression. The cross-sectionally augmented Dickey-Fuller regression (CADF) is then defined as

$$
\Delta y_{i t}=\mu_{i}+\omega_{i} t+\alpha_{i} y_{i, t-1}+\sum_{j=1}^{p_{i}} \lambda_{i j} \Delta y_{i, t-j}+v_{i} \bar{y}_{t-1}+\sum_{j=0}^{p_{i}} \varpi_{i j} \Delta \bar{y}_{i, t-j}+\epsilon_{i t}
$$

where $\epsilon_{i t}$ denotes an i.i.d. error term and $\bar{y}_{t}$ is the cross-section mean. The other parameters and variables are the same as in the ADF equation (8). The CADF equation formalizes a fairly novel idea that even individual unit root tests should account for mutual dependence among regions. Let $\tilde{t}_{i, T_{i}, N}\left(p_{i}\right)$ be the t-statistic for $\alpha_{i}=0$ (a unit root) in the CADF regression. Setting $p_{i}=p=1$ for all $i$ 's together with an assumption of a balanced panel, which is satisfied in our case, results in $\tilde{t}_{i, T_{i}, N}\left(p_{i}\right)=\tilde{t}_{i}(T, N)$. Following Pesaran [2007], we restrict the values of this statistic to the interval between -6.42 and 1.70 .

We conduct the CADF test using the logarithms of house prices, rents, CPI, construction costs, income, population, and mortgage rates. Results are reported in Exhibit 5. For all variables, more than one half of the series do contain unit roots. There are only four areas with stationary house prices, for example DetroitLivonia-Dearborn. The largest number of stationary series can be found for the mortgage rate, 10 out of 22 . Exhibit 5 can be used to evaluate the possibility of bubble occurrence in a given region. Fundamentals in the Detroit area are all stationary so it does not come as a surprise that the house price index is also stationary. St. Louis provides a similar story. Even though only the house price is stationary, t-statistics for all fundamental factors are fairly negative and relatively 
close to the critical values of the CADF test. On the other hand, the stationarity of the area San-Diego-Carlsbad-San Marcos seems to be driven by just two fundamentals, rents and mortgage rate. Looking at Boston-Quincy, we see that both the prices and the market fundamentals are non-stationary, which means that prices are not necessarily higher due to a bubble. However, there are regions such as Houston-Sugar Land-Baytown or Miami-Miami Beach-Kendall where the house price contains a unit root in spite of some stationary fundamentals. This suggests a potential bubble presence.

A natural next step is to find whether a discrepancy between house prices and fundamentals exists at the national level. In other words, we would like to explore if the non-alignment of house prices and fundamentals is a local phenomenon typical for a few regions, or if this non-alignment leads to a break in the relationship between house prices and fundamentals in the U.S. housing market. For this purpose we use panel data stationarity tests that combine regional test results. An intuitive and widely used panel data unit root test along these lines is developed in Im, Pesaran, and Shin [2003]. This test simply averages across regions the individual t-statistics for $\alpha_{i}$ in the ADF regressions. We use an updated version of this test proposed in Pesaran [2007], which is robust to the cross-section dependence:

$$
\bar{t}^{\dagger}=\frac{1}{N} \sum_{i=1}^{N} \tilde{t}_{i}(N, T)
$$

The null and alternative hypotheses are, respectively,

$$
\begin{aligned}
& H_{0}: \alpha_{i}=0 \text { for } i=1,2, \ldots, N \\
& H_{1}: \begin{cases}\alpha_{i}=0 & \text { for } i=1,2, \ldots, N_{1} \\
\alpha_{i}<0 & \text { for } i=N_{1}+1, N_{1}+2, \ldots, N\end{cases}
\end{aligned}
$$

Regions can be ordered as needed. $H_{1}$ states that at least one of the $N$ series is stationary. A rejection of the null hypothesis implies that some series are stationary. Failure to reject indicates that after looking at $N$ realizations of a given process we are not able to exclude the possibility that all series are in fact non-stationary.

We conduct the CIPS test for logs and growth rates (differences in logs) for 
our seven variables available as panels of data. Results are given in Exhibit 6. The null hypothesis of a unit root in logs in all regions is accepted for the house price, CPI, and income. All the growth rates are stationary. Since stock market wealth is not a panel but an aggregate data series, unit root tests results for it are the same as in Exhibit 3. In other words, the logarithm of stock market wealth is not stationary in levels, but stationary in first differences. Since the price dynamics do not correspond to a fundamental factor if the factor is stationary but price is not, the house price development does not reflect movements in rents, construction costs, regional population, and local mortgage rates. However, a (rational) bubble might not exist if the house price is cointegrated with at least one of the three non-stationary fundamentals: CPI, personal income, and stock market wealth. Naturally, the next step is testing for panel data cointegration.

A widely used test for cointegration in panel data is constructed by Pedroni [1999, 2004] and is based on the following cointegrating regression:

$$
y_{i, t}=\mu_{i}+\omega_{i} t+\psi_{1 i} x_{1, i, t}+\ldots+\psi_{M i} x_{M, i, t}+\zeta_{i, t} \text { for } t=1, \ldots, T, i=1, \ldots, N \text {. }
$$

The slope vector $\psi_{i}$ defines the cointegrating relationship between the dependent variable $y$ (house price) and explanatory variables $x_{m}, m=1, \ldots, M$ (fundamentals). Let us define $\gamma_{i}$ as the autoregressive coefficient of the error term $\zeta_{i}$. The null hypothesis of no cointegration $H_{0}: \gamma_{i}=1$ for all $i$ is tested against the alternative $H_{1}: \gamma_{i}<1$ for all $i$ where we do not assume any common value for the autoregressive coefficient. The test for cointegration is a test of the stationarity of $\zeta_{i}$ while accounting for the fact that $\psi_{i}$ 's have to be estimated. Otherwise, the CIPS test would suffice. We use the Pedroni group ADF t-statistic, which he has shown to have the best finite sample properties. The group t-statistic asymptotically converges to the standardized normal distribution under the assumption of no cross-sectional dependence. Because this assumption is violated in our case, we use bootstraping similar to Gallin [2006] and Maddala and $\mathrm{Wu}$ [1999] to generate critical values.

We conduct the group-t Pedroni test for cointegration between house price and several sets of explanatory variables: only CPI, only income, both CPI and income, and CPI, income and stock wealth. Our results are in Exhibit 7 and 
indicate that the house price and any combination of non-stationary fundamentals are not cointegrated. Combined with the panel data unit root tests, it appears that house prices do not reflect movements in fundamental factors, i.e., there is a house price bubble.

\section{CONCLUSION}

This paper used a unique set of regional and aggregate data on house prices and fundamental variables in order to investigate whether the U.S. housing market experienced a bubble in recent years. The fundamental variables included house rent, mortgage rate, CPI, population, personal income, building cost, and stock market wealth. Based on the evidence from univariate and panel unit root and cointegration tests, we conclude that most likely there is a house price bubble in the U.S.

This result may imply that house prices might substantially decline in subsequent years. Given the history of the slow adjustment of house prices to fundamentals in previous episodes of possible bubbles, we argue that house prices will not drop sharply, but rather decrease gradually over a long period of time. Also, it is unlikely that house prices will decline in all U.S. cities and Metropolitan Statistical Areas. However, the most likely candidates for substantial drops in house prices are coastal cities where these prices have been especially high in recent years. 


\section{ENDNOTES}

Petr Zemčík would like to acknowledge support from the Marie Curie International Reintegration Grant \# 014864.

${ }^{1}$ See Calhoun [1996] for the methodology of the calculation of this price index.

${ }^{2}$ In the aggregate level evidence section construction wage is a proxy for building costs. This proxy may be imperfect because it does not include the price of construction materials and the amount of different hours of labor needed to finish particular construction works. The panel data section uses the building costs index, which is a better measure of the total costs of construction. Unfortunately, this index is not available in monthly or quarterly frequency for all the periods needed for the aggregate data analysis. Hence, in this analysis construction wage serves as a proxy for construction costs.

${ }^{3}$ ENR [2002, 2007] publishes these cost series, and Grogan [2007] provides a description of these indexes.

${ }^{4}$ The Federal Housing Finance Board provides data for the last two quarters of 2005 only. Hence, the average of these two quarters serves as an estimate of the annual mortgage interest rate for 2005 .

${ }^{5}$ Case and Shiller [2003] also discuss this explanation. 


\section{REFERENCES}

Bucks, B.K., A.B. Kennikell, and K.B. Moore. "Recent Changes in U.S. Family Finances: Evidence from the 2001 and 2004 Survey of Consumer Finances." Federal Reserve Bulletin, 2006.

Calhoun, C.A. "OFHEO House Price Indexes: HPI Technical Description." Office of Federal Housing Enterprise Oversight (1996).

Case, K.E., and R.J. Shiller. "Is There a Bubble in the Housing Market?" Brookings Papers on Economic Activity, No. 2 (2003), pp. 299-342.

Davidson, R., and J. MacKinnon. Estimation and Inference in Econometrics. New York: Oxford University Press, 1993.

Engle, R.F., and C.W.J. Granger. "Co-integration and Error Correction: Representation, Estimation, and Testing." Econometrica, Vol. 55, No. 2 (1987), pp. 251-276.

"ENR Cost Indexes in 20 cities, 1976-2002." ENR: Engineering News-Record, Vol. 248, No. 10 (2002), p. 80.

"ENR Cost Indexes in 20 cities, 1981-2007." ENR: Engineering News-Record, Vol. 258, No. 11 (2007), p. 53.

Gallin, J. "The Long-Run Relationship between House Prices and Income: Evidence from Local Housing Markets." Real Estate Economics, Vol. 34, No. 3 (2006), pp. 417-438.

Grogan, T. "How to Use ENR's Cost Indexes," ENR: Engineering News-Record, Vol. 258, No. 11 (2007), p. 37.

Himmelberg, C., C. Mayer, and T. Sinai. "Assessing High House Prices: Bubbles, Fundamentals, and Misperceptions." Journal of Economic Perspectives, Vol. 19, No. 4 (2005), pp. 67-92.

Im, K.S., M.H. Pesaran, and Y. Shin. "Testing for Unit Roots in Heterogeneous Panels." Journal of Econometrics, Vol. 115 (2003), pp. 53-74. 
Maddala, G.S. and S. Wu. "A Comparative Study of Unit Root Tests with Panel Data and a new Simple Test," Oxford Bulletin of Economics and Statistics 61 (1999), pp. 631-52.

McCarthy, J., and R. Peach. "Are Home Prices the Next Bubble?" Federal Reserve Bank of New York Economic Policy Review, Vol. 10, No. 3 (2004), pp. 1-17.

Mikhed, V. and P. Zemčík. "Testing for Bubbles in Housing Markets: A Panel Data Approach," forthcoming in the CERGE-EI Working Paper Series (2007).

Pedroni, P. "Critical Values for Cointegration Tests in Heterogeneous Panels with Multiple Regressors." Oxford Bulletin of Economics and Statistics, Vol. 61 (1999), pp. 653-670.

Pedroni, P. "Panel Cointegration; Asymptotic and Finite Sample Properties of Pooled Time Series Tests with an Application to the PPP Hypothesis." Econometric Theory, Vol. 20, No. 3 (2004), pp. 597-625.

Pesaran M.H. "General Diagnostic Tests for Cross Section Dependence in Panels." Working Paper No. 1229, CESIFO, 2004.

Pesaran M.H. "A Simple Panel Unit Root Test in the Presence of Cross Section Dependence." Journal of Applied Econometrics, Vol. 22, No. 2 (2007), pp. 265-312.

Shiller, R.J. Irrational Exuberance. Princeton: Princeton University Press, 2005.

Smith, M., and G. Smith. "Bubble, Bubble, Where's the Housing Bubble?" Brookings Papers on Economic Activity, No. 1 (2006), pp. 1-50.

Stiglitz, J.E. "Symposium on Bubbles." Journal of Economic Perspectives, Vol. 4, No. 2 (1990), pp. 13-18. 
EXHIBIT 1: House price and fundamentals, $1 / 2$

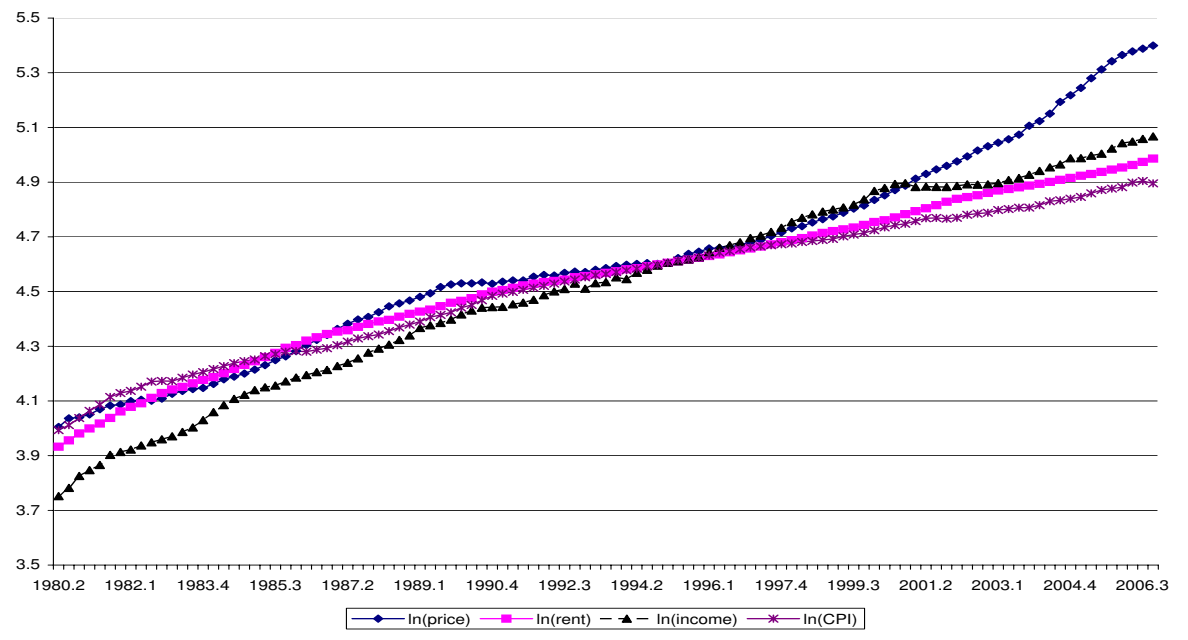

EXHIBIT 2: House price and fundamentals, 2/2

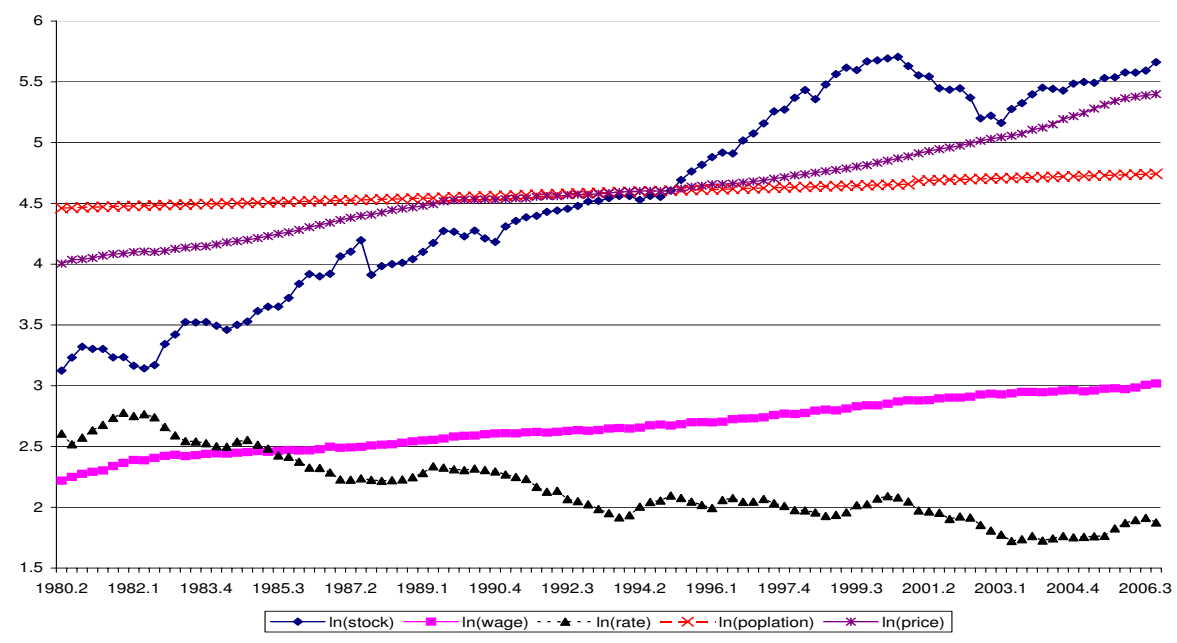


EXHIBIT 3: A summary of ADF statistics for aggregate U.S. data (1980:q22006:q4)

Notes:

(1) Significance at the $1 \%, 5 \%$, and $10 \%$ levels is denoted as $* * *, * *$, and $*$, respectively.

(2) The null hypothesis is that of a unit root.

(3) ADF test statistics with four lags and trends are reported for levels and first differences.

price rent CPI wage income population rate stock

$\begin{array}{lllllllll}\text { Ln } & -1.62 & -2.35 & -1.43 & -4.99^{* * *} & -2.21 & -1.87 & -2.92 & -1.85 \\ \text { Growth } & -2.62 & -2.05 & -5.48^{* * *} & -3.49^{* *} & -5.26^{* * *} & -4.56^{* * *} & -4.92^{* * *} & -4.40^{* * *}\end{array}$

EXHIBIT 4: Diagnostic tests for cross section dependence in panels

Notes:

(1) Included series are the housing price index (price), tenants' rent (rent), Consumer Price Index (cpi), construction costs (cost), regional income (inc, the series ends in 2005), population (pop), and the mortgage rate (rate).

(2) ADF regression: intercept, trend, and the first lag of the dependent variable.

(3) The null hypothesis is that of no cross sectional dependence.

(4) Significance at the $1 \%, 5 \%$, and $10 \%$ levels is denoted as ***, **, and *, respectively. 


$$
\text { price }
$$

$$
\text { rent }
$$

$$
\text { cpi }
$$

cost

Ln $9.25^{* * *}$

$12.83^{* * *}$

$42.81^{* * *}$

$23.40^{* * *}$

$47.70 * * *$

$5.15^{* * *}$

$68.28^{* * *}$

Growth $-3.02^{* * *}$
$-2.89 * * *$

$-2.58 * * *$
$-2.51^{* * *}$

$-0.29$ 


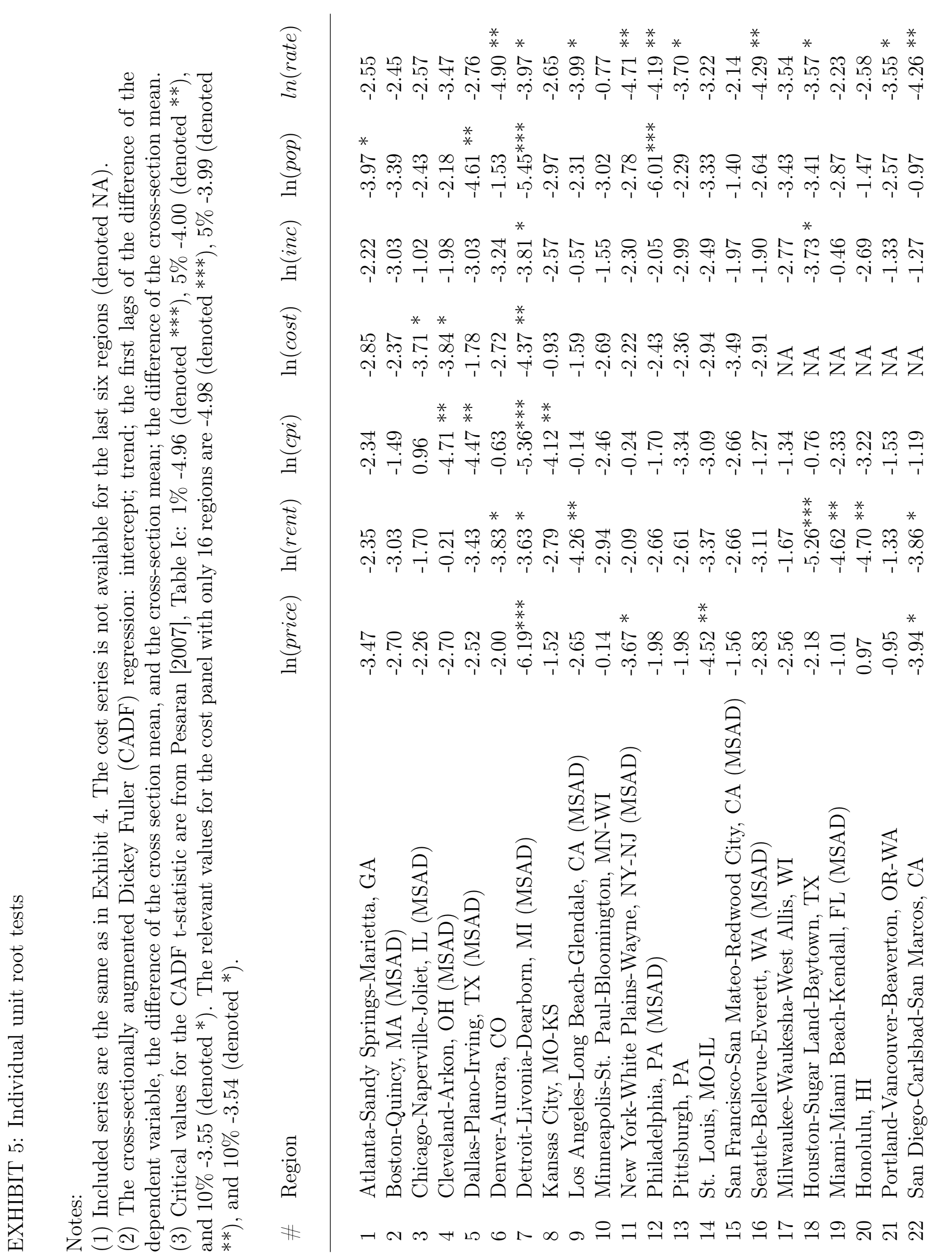


EXHIBIT 6: Panel data unit root tests

Notes:

(1) Included series are the same as in Exhibit 4.

(2) The CIPS test is based on the individual cross-sectionally augmented Dickey Fuller $(\mathrm{CADF})$ regressions with intercept; trend; the first lags of the difference of the dependent variable, the difference of the cross section mean, and the crosssection mean; and the difference of the cross-section mean. Critical values for the CIPS statistic are from Pesaran [2007], Table IIc: 1\% -2.92, 5\% -2.73, 10\%-2.63. The relevant values for the cost panel with only 16 regions are $1 \%-3.01,5 \%-2.78$, and $10 \%-2.67$.

(3) Significance at the $1 \%, 5 \%$, and $10 \%$ levels is denoted as ***, **, and *, respectively.

(4) The null hypothesis is that of a unit root (it assumes an individual unit root process).

price rent cpi cost inc pop rate

$\begin{array}{llllllll}\text { Ln } & -2.38 & -3.01^{* * *} & -2.16 & -2.70 * & -2.23 & -2.96^{* * *} & -3.28^{* * *} \\ \text { Growth } & -3.89^{* * *} & -3.71^{* * *} & -3.95^{* * *} & -3.91^{* * *} & -4.71^{* * *} & -3.54^{* * *} & -2.68 *\end{array}$


EXHIBIT 7: Panel data cointegration tests

Notes:

(1) The dependent variable is the housing price index (price) and the explanatory variables are the consumer price index (cpi), stock market wealth (stock), and regional income level (inc), which ends in 2005.

(2) The cointegration test is the group t-statistic from Pedroni [1999, 2004]. We report bootstrapped critical values.

(3) Significance at the $1 \%, 5 \%$, and $10 \%$ levels is denoted as ***, **, and ${ }^{*}$, respectively.

(4) The null hypothesis is that of no cointgeration.

critical values

\begin{tabular}{lllll} 
x's & group t & $1 \%$ & $5 \%$ & $10 \%$ \\
\hline & & & & \\
cpi & -3.36 & -6.61 & -5.18 & -4.41 \\
inc & -1.47 & -6.92 & -5.31 & -4.49 \\
cpi, inc & -0.33 & -7.00 & -5.75 & -5.01 \\
cpi, inc, stock & 1.54 & -7.77 & -6.34 & -5.48
\end{tabular}


Individual researchers, as well as the on-line and printed versions of the CERGE-EI Working Papers (including their dissemination) were supported from the following institutional grants:

- Center of Advanced Political Economy Research [Centrum pro pokročilá politickoekonomická studia], No. LC542, (2005-2009),

- Economic Aspects of EU and EMU Entry [Ekonomické aspekty vstupu do Evropské unie a Evropské měnové unie], No. AVOZ70850503, (2005-2010);

- Economic Impact of European Integration on the Czech Republic [Ekonomické dopady evropské integrace na ČR], No. MSM0021620846, (2005-2011);

Specific research support and/or other grants the researchers/publications benefited from are acknowledged at the beginning of the Paper.

(c) Vyacheslav Mikhed, Petr Zemčík, 2007

All rights reserved. No part of this publication may be reproduced, stored in a retrieval system or transmitted in any form or by any means, electronic, mechanical or photocopying, recording, or otherwise without the prior permission of the publisher.

Published by

Charles University in Prague, Center for Economic Research and Graduate Education (CERGE) and

Economics Institute ASCR, v. v. i. (EI)

CERGE-El, Politických vězňů 7, 11121 Prague 1, tel.: +420 224005 153, Czech Republic.

Printed by CERGE-EI, Prague

Subscription: CERGE-EI homepage: http://www.cerge-ei.cz

Editors: Directors of CERGE and EI

Managing editors: Deputy Directors for Research of CERGE and EI

ISSN 1211-3298

ISBN 978-80-7343-136-5 (Univerzita Karlova. Centrum pro ekonomický výzkum

a doktorské studium)

ISBN 978-80-7344-125-8 (Národohospodářský ústav AV ČR, v. v. i.) 
CERGE-EI

P.O.BOX 882

Politických vězňů 7

11121 Praha 1

Czech Republic http://www.cerge-ei.cz 